\title{
EU protected area network did not prevent a country wide population decline in a threatened grassland bird
}

\author{
João P Silva ${ }^{\text {Corresp.. }}$ 1, 2,3 $^{\text {， Ricardo Correia }}{ }^{4,5,6}$, Hany Alonso ${ }^{7}$, Ricardo C Martins ${ }^{1,2}$, Marcello D'Amico ${ }^{1,2}$, Ana \\ Delgado $^{2}$, Hugo Sampaio ${ }^{8}$, Carlos Godinho ${ }^{9}$, Francisco Moreira ${ }^{1,2}$ \\ 1 \\ University of Porto, REN Biodiversity Chair, CIBIO/InBIO - Research Centre in Biodiversity and Genetic Resources, Vairão, Portugal \\ 2 Institute of Agronomy, University of Lisbon, CEABN/InBIO - Centre for Applied Ecology "Prof Baeta Neves", Lisbon, Portugal \\ 3 Faculty of Sciences, University of Lisbon, CE3c - Centre for Ecology, Evolution and Environmental Changes, Lisbon, Portugal \\ 4 Federal University of Alagoas, Institute of Biological and Health Sciences, Maceió, Alagoas, Brazil \\ 5 University of Oxford, School of Geography and the Environment, Oxford, United Kingdom \\ 6 Department of Biology, University of Aveiro, CESAM - Centre for Environmental and Marine Studies, Aveiro, Portugal \\ 7 Pólo de Évora, University of Évora, CIBIO/InBIO - Research Center in Biodiversity and Genetic Resources, Évora, Portugal \\ 8 SPEA - Sociedade Portuguesa para o Estudo das Aves, Lisbon, Portugal \\ 9 ICAAM - Instituto de Ciências Agrárias e Ambientais Mediterrânicas, Universidade de Évora, Laboratório de Ornitologia, Évora, Portugal \\ Corresponding Author: João P Silva \\ Email address: jpsilva@cibio.up.pt
}

Background. Few studies have assessed the effectiveness of the Protected Area networks on the conservation status of target species. Here, we assess the effectiveness of the Portuguese Natura 2000 (the European Union network of protected areas) in maintaining a species included in the Annex I of the Bird Directive, namely the population of a priority farmland bird, the little bustard Tetrax tetrax.

Methods. We measured the effectiveness of the Natura 2000 by comparing population trends across time (2003-2006 and 2016) in 51 areas, 21 of which within 12 Special Protection Areas (SPA) that were mostly designated for farmland bird conservation and another 30 areas without EU protection.

Results. Overall, the national population is estimated to have declined $49 \%$ over the last $10-14$ years. This loss was found to be proportionally larger outside SPA (64\% decline) compared to losses within SPA (25\% decline). However, the absolute male density decline was significantly larger within SPA .

Discussion. In spite of holding higher population densities and having prevented habitat loss, we conclude that Natura 2000 was not effective in buffering against the overall bustard population decline. Results show that the mere designation of SPA in farmland is not enough to secure species populations and has to be combined with agricultural policies and investment to maintain not only habitat availability but also habitat quality. 


\section{EU protected area network did not prevent a country wide population decline}

\section{2 in a threatened grassland bird}

3

4 João P. Silva ${ }^{1,2,3}$, Ricardo A. Correia ${ }^{4,5,6}$, Hany Alonso ${ }^{7}$, Ricardo C. Martins ${ }^{1,2}$, Marcello

5 D’Amico ${ }^{1,2}$, Ana Delgado ${ }^{2}$, Hugo Sampaio $^{8}$, Carlos Godinho $^{9}$, Francisco Moreira ${ }^{1,2}$

6

$7 \quad{ }^{1}$ REN Biodiversity Chair, CIBIO/InBIO - Research Centre in Biodiversity and Genetic

8 Resources, Universidade do Porto, Portugal.

$9{ }^{2} \mathrm{CEABN} / \mathrm{InBIO}$, Institute of Agronomy, University of Lisbon, Lisbon, Portugal.

$10{ }^{3} \mathrm{cE} 3 \mathrm{c}$ - Centre for Ecology, Evolution and Environmental Changes; Faculty of Sciences,

11 University of Lisbon, Lisbon, Portugal.

$12{ }^{4}$ Institute of Biological and Health Sciences, Federal University of Alagoas, Maceió, Alagoas,

13 Brazil.

$14{ }^{5}$ School of Geography and the Environment, University of Oxford, Oxford, United Kingdom.

${ }^{6}$ DBIO \& CESAM-Centre for Environmental and Marine Studies, University of Aveiro, Aveiro,

16 Portugal

$17{ }^{7} \mathrm{CIBIO} / \mathrm{InBIO}$ - Research Center in Biodiversity and Genetic Resources, Pólo de Évora,

18 University of Évora, Department of Biology, Évora, Portugal.

$19{ }^{8}$ Sociedade Portuguesa para o Estudo das Aves, Lisbon, Portugal.

${ }^{9}$ Laboratório de Ornitologia, ICAAM - Instituto de Ciências Agrárias e Ambientais

21 Mediterrânicas, University of Évora, Évora, Portugal. 
23 Corresponding author: João Paulo Silva 


\section{Abstract}

28 Background. Few studies have assessed the effectiveness of the Protected Area networks on the

29 conservation status of target species. Here, we assess the effectiveness of the Portuguese Natura

302000 (the European Union network of protected areas) in maintaining a species included in the

31 Annex I of the Bird Directive, namely the population of a priority farmland bird, the little bustard

32 Tetrax tetrax.

33 Methods. We measured the effectiveness of the Natura 2000 by comparing population trends 34 across time (2003-2006 and 2016) in 51 areas, 21 of which within 12 Special Protection Areas

35 (SPA) that were mostly designated for farmland bird conservation and another 30 areas without 36 EU protection.

37 Results. Overall, the national population is estimated to have declined $49 \%$ over the last $10-14$ 38 years. This loss was found to be proportionally larger outside SPA (64\% decline) compared to 39 losses within SPA (25\% decline). However, the absolute male density decline was significantly 40 larger within SPA.

41 Discussion. In spite of holding higher population densities and having prevented habitat loss, we 42 conclude that Natura 2000 was not effective in buffering against the overall bustard population 43 decline. Results show that the mere designation of SPA in farmland is not enough to secure 44 species populations and has to be combined with agricultural policies and investment to maintain 45 not only habitat availability but also habitat quality. 


\section{Introduction}

Protected areas constitute key tools for conserving biodiversity (Marton-Lefèvre, 2014; Watson et al., 2014). The European Union (EU) has set up the largest coordinated network of protected areas in the world - Natura 2000. Covering 18\% of EU's land area, it comprises Special Protection Areas (SPA) and Special Areas of Conservation (SAC) designated respectively under the Birds Directive (2009/147/EC) and the Habitats Directive (1992/43/EEC). EU countries are required to manage Natura 2000 sites to maintain or improve the conservation status of species and habitats listed in these Directives. Therefore, monitoring species populations, particularly

57 those from target species, is essential to evaluate the effectiveness of Natura 2000.

Most research evaluating the effectiveness of the Natura 2000 protected area network has focused on assessing its spatial coverage of biodiversity values (e.g. Abellán \& Sanchéz-Fernández, 2014), but much less is known about its effect on species persistence or population trends (e.g. as a consequence of habitat loss or climate change) due to a lack of temporal data (e.g. Pellisier et al., 2013). Most recent studies compare population trends across species with different conservation priority levels (e.g. Sanderson et al., 2016), while rigorous studies based on empirical designs to compare conservation outcomes in areas with and without exposure to conservation policy instruments are still scarce (Miteva, Pattanayak \& Ferraro, 2012). Even for taxa with abundant information on population sizes, such as birds, few studies have assessed the

67 effectiveness of the SPA network on the conservation status of target species (Orlikowska et al., 68 2016). 
69 Farmland birds are of high conservation concern in Europe, showing a steep population decline

70 across the continent mainly due to ongoing intensification of agricultural practices (BirdLife

71 International, 2004; Donald et al., 2006). At the European scale, however, few studies assessed

72 whether SPAs designated in agricultural land are delivering any positive effects on farmland bird

73 populations (Gamero et al., 2016). For example, Pellissier et al. (2013) used a national breeding

74 bird survey to contrast species population trends in the period 2001-2010 in plots located within

75 and outside Natura 2000 sites in France and found no significant differences. They concluded

76 that the network of protected areas was established too recently to allow an assessment of its

77 influence on population trends. In contrast, and at a larger scale, Gamero et al. (2016) used country wide information for a set of 25 EU countries. This study reported that species listed in

Annex I of the Birds Directive (species with higher conservation status and for which EU

Member States are obliged to implement special conservation measures) had higher population growth rates (during 1981-2012) in countries with a higher proportion of land designated as SPA. They conclude that EU policies seem to generally attenuate the declines of farmland bird populations, but do not reverse them.

The Portuguese farmland bird SPA network was created between 1994 and 2008, and consists of 13 areas covering over 195,000 ha which were delineated based on detailed information on the spatial patterns of occurrence of priority species listed in Annex I. Here, we assess the effectiveness of this SPA network in maintaining the population of a priority farmland bird, the little bustard Tetrax tetrax, a species that has undergone a major decline and breeding range reduction since the beginning of the last century (BirdLife International, 2016). We expected that populations within SPA would show more favourable trends when compared to populations in farmland areas outside SPAs. For this purpose, we compared estimates of breeding population 
92 size and density over a decade (2003-2006 to 2016) within and outside SPAs. We further

93 assessed trends in the availability of grasslands comprising fallow lands and extensive pastures,

94 the preferred breeding habitat of the species (Morales, Garcia \& Arroyo, 2005; Silva, Palmeirim

95 \& Moreira, 2010; Moreira et al., 2012).

\section{Methods}

\section{Study areas}

The large majority of the little bustard population in Portugal is concentrated in Alentejo, Southern Portugal (Equipa Atlas, 2008). A first population survey was carried out in the region during 2003-2006 in the scope of a EU LIFE project (LIFE02NAT/P/8476) (Silva et al., 2006). This first survey was based on a network of 81 survey areas, from which 21 were located within 12 SPAs and the remaining 60 were outside SPAs. Each SPA was considered as a single survey area, with the exception of the three largest areas (over 10,000 ha of farmland) which accounted for between two and six survey areas. The size of SPA survey areas ranged from 1715 and 4718 ha $($ mean $=3025$ ha $)$. Non-SPA survey areas consisted of approximately 2500 ha quadrats defined as follows: (i) on a first stage, we delimited $10 \times 10 \mathrm{~km}$ UTM quadrats whose land surface was covered by more than $40 \%$ of open agricultural and pastoral land area (representing the potential habitat for the species) based on information from Corine Land Cover 2000. These quadrats overlapped to a great extent with the quadrats where the presence of the species was recorded in the Portuguese Breeding Bird Atlas (Equipa Atlas, 2008); (ii) on a second stage, a maximum of two $5 \times 5 \mathrm{~km}$ areas within each of the $10 \times 10 \mathrm{~km}$ UTM quadrats identified in the 
113 first stage were randomly selected for surveying. Ten additional areas with potential for the

114 species but not fitting these criteria were also surveyed (see S1). Overall, a total of 60 non-SPA

115 areas, stratified across the four main sub-regions of Alentejo (Fig. 1) were censused during this

116 first period (2003-2006).

117 In 2016, all previously surveyed areas within SPAs were revisited but, in non-SPA areas, the

118 number of surveyed areas in each $10 \times 10 \mathrm{~km}$ quadrat was reduced to just one $5 \times 5 \mathrm{~km}$ area due

119 to logistic constrains. The final result was a total of 51 survey areas sampled in both periods (Fig.

120 1), of which 21 were located within SPAs designated for farmland bird conservation and 30 were

121 non-SPAs areas with potential habitat for the species.

\section{Little bustard counts}

124 Little bustard population densities were censused using a standardized protocol based on

125 estimating male densities. In each of the survey areas we estimated male density from a network

126 of survey points previously defined along dirt tracks and distanced by $600 \mathrm{~m}$ from each other and

127 from disturbance factors, such as paved roads or inhabited houses (more details in Moreira et al.,

128 2012). The dirt tracks were covered by car in early morning and late afternoon during April-May

129 and each point was surveyed during 5 minutes within a prospecting radius of $250 \mathrm{~m}$ to detect

130 little bustard males. Because of ample habitat availability, the location of survey points in SPAs

131 fall mostly in farmland habitats, but in non-SPAs, some survey points could be located in

132 unsuitable habitats (e.g. forest, scrubland). At each survey point the proportion of fallow land and 133 pastures, hereafter designated grasslands, was assessed by estimating visually, within eight equal 
134 sections of the $250 \mathrm{~m}$ buffer, the number of sections where this land use was dominant. This

135 method allowed for a rough estimation of the available main breeding habitat for the species

136 (Morales, García \& Arroyo, 2005; Silva, Palmeirim \& Moreira, 2010; Moreira et al., 2012).

137 Most points surveyed during the 2003-2006 period were surveyed again in 2016. The points that

138 became inaccessible in $2016(<1 \%$ of the sampled points $)$ were replaced by new ones, following

139 the same requisites as mentioned above. The network of survey points covered each survey area

140 at an average density of 0.96 points $/ \mathrm{km}^{2}($ median $=1$, range $=0.33-2.12)$. Overall, a total of

1412326 and 1441 survey points were sampled in 2003-2006 and resampled in 2016, respectively.

\section{Data processing and analysis}

144 Population estimates

145 For each survey area and sampling period, mean male density (and 95\% confidence intervals)

146 was estimated from the number of males found within the $250 \mathrm{~m}$ buffer of sampled points. The

147 population estimate for each site was then calculated by extrapolating the mean density calculated

148 from the survey points to the total area of potential habitat when within an SPA or to whole

149 survey area if outside SPA (see Supporting Information for a detailed description). For the large

150 SPAs with more than one sampled area, the mean density was obtained by calculating the

151 average density across areas. We assessed the proportional increase or decrease in the estimated

152 population sizes for the two sampled periods, across the two types of areas (SPA or non-SPA). 
154

155

156

157

158

159

160

161

162

163

164

165

166

167

168

169

170

171

172

173

Density and grassland habitat differences between surveys and protection status

For the subset of 51 areas sampled in both periods, we modelled the effect of protection status (SPA versus non-SPA) and survey period (2003-2006 or 2016) on population densities (males $/ \mathrm{km}^{2}$ ) and on the amount of suitable grassland habitat $\left(\mathrm{km}^{2}\right)$. The amount of available grassland habitat was calculated multiplying the surface of each survey area by the estimated proportion of this land use derived from field estimates. We used generalized linear mixed models (GLMMs) with Gaussian distribution and identity-link function, implemented in package lme4, for both little bustard male density and grassland habitat availability. Protection status and survey period (including interactions) were considered as fixed effects in the model and survey area was included as a random effect to account for lack of independence within areas. Model fit was assessed using conditional and marginal $\mathrm{r}^{2}$ values (Nakagawa and Schielzeth, 2013). All analyses were implemented in R Software v3.1.3 (R Core Team, 2015) and figures were elaborated using the ggplot2 library available for the same software package.

\section{Results}

The results show an overall decline of breeding little bustards across most of its distribution range. The Portuguese national population estimate in $2003-2006$ was of 17,418 males (95\% CI: 13,074 - 21,762; Table S1). In 2016, it was estimated at 8900 males (95\% CI: 5008 - 12,836; Table S1), representing an overall national decline of 48,9\%. The amount of losses was greater 
174 outside SPA (10,724 to 3892 males; -63.7\%) compared to SPA areas (6695 to 5008 males; $17525.2 \%)$.

176 In the subset of areas monitored in both surveys, results show a higher male density in SPA

177 survey areas compared to non-SPA survey areas and a strong decline in density between surveys

178 (Fig. 2). GLMM results showed a significant interaction survey period and protection status

179 (Table 1) and indicate that, in absolute terms, density declines were even larger within SPA.

180 Patterns for grassland availability showed higher habitat availability inside SPA and a higher

181 habitat loss across time outside SPA (Fig. 2; Table 1).

184 Discussion

\section{A generalised population collapse}

The 2016 survey showed a drastic 49\% decline compared to 2003-2006. In 2003-2006 the conservation status of the species was mostly favourable across its range, and exceptionally high breeding densities were found in many SPAs, among the highest recorded for the species (Silva et al., 2014). The overall average density outside SPAs was also relatively high when compared with the densities reported across its western range (Martínez \& De Juana, 1996; Jiguet, Arroyo

191 \& Bretagnolle, 2000). and habitat loss as consequence of agricultural intensification. That was the case of the French 
194 population that in the late $20^{\text {th }}$ century, over a 17 -year period, experienced a very rapid and 195 dramatic decline of over 90\% (Inchausti \& Bretagnolle, 2005). More recently, declines have been

196 197

198

199

200

201

202

203

204

205

206

207

208

209

210

211

212

213 The network of Natura 2000 SPAs designated for grassland bird conservation covers all

214 Portuguese regions holding the most important little bustard populations (Silva et al., 2006). This 
215 is also confirmed by the fact that population densities in 2003-2006 were much higher in SPAs

216 than in non-SPAs. However, coverage of protected areas by itself may be insufficient to ensure a

217 favourable conservation status of target species (Watson et al., 2014), and effective management

218 needs to be put in place to ensure the biological needs of these species (Leverington et al., 2010).

219 Taking into account the factors driving negative little bustard population trends in other regions

220 of Europe (Iñigo \& Borov, 2010), habitat loss would be expected to be the main driver of

221 population decline, both outside and within SPAs. However, our indicator of grassland habitat

222 availability, although somewhat crude, suggests that SPAs did manage to maintain the amount of

223 habitat over time, whereas habitat loss continued to occur outside SPAs (e.g. with the expansion

224 of irrigated and permanent crops). Natura 2000 areas benefit from legal mechanisms that prevent

225 structural land use changes, for example interdicting the conversion of farmland to forestry, or

226 preventing the installation of infrastructures (e.g. roads, transmission power lines, buildings)

227 without impact assessment and compensatory measures. In spite of this legal protection and its

228 effectiveness in maintaining habitat availability, significant breeding density losses were recorded

229 in these areas.

230 A probable explanation to population declines within SPAs is that they did not manage to

231 maintain habitat quality. Permanent pastures, which increased by up to $41 \%$ over a 10 -year

232 period as result of EU Common Agricultural Policies (CAP) incentives (INE, 2013; Ribeiro et

$233 a l ., 2014$ ), have been progressively installed in previously extensively managed grasslands across

234 the species range. Livestock density has also increased significantly over a similar period

235 (Pimenta, Fernandes \& Minhoto, 2015). This intensification process may potentially affect

236 vegetation structure and ultimately grassland quality for the little bustard, particularly for nesting 
237 females that require taller vegetation (Morales et al., 2008; Silva et al., 2014), or still expose

238 individuals or families to predation, due to the less dense sward structure and shorter vegetation

239 (Tarjuelo et al., 2013; Silva et al., 2014). It may also impact food availability which is crucial for

240 the development of chicks particularly during the first weeks of life (Jiguet, 2002). Although

241 these management changes occurred both within and outside SPA, their impact is expected to be

242 stronger in higher quality areas. The importance of setting an adequate grassland management

243 scheme is highlighted by the fact that the only two SPA registering a population increase (Castro

244 Verde and Vale do Guadiana; Table S2), were the ones where a significant number of farmers

245 joined an existing agri-environmental program promoting extensive agricultural practices and

246 establishing thresholds for grazing intensity (Pinto, Rocha \& Moreira, 2005; Santana et al.,

247 2014).

248 Another explanatory hypothesis is that generalized habitat degradation outside SPAs, nearby key 249 conservation areas, may have led to larger post-breeding migration movements (Silva, Faria \&

250 Catry, 2007; García de la Morena et al., 2015), exposing bustards to higher levels of energy

251 expenditure and to a greater mortality risk with anthropogenic infrastructures (Silva et al. 2007).

252 Climate warming may also be impacting grassland quality by drying prematurely the vegetation

253 and consequently limiting trophic resources. High anthropogenic mortality has been recently

254 found in Iberia, with mortality annual rates estimated between 3.4 and 3.8\% due to collisions

255 with power lines and another $2.4-3 \%$ due to illegal killing, possibly contributing to the depletion

256 of the population (Marcelino et al. 2017). Even though other factors are likely to be contributing

257 to the decline of the little bustard, it is within the few SPAs with successful management schemes

258 that breeding densities are stable or incrementing. The fact that some populations are

259 incrementing and other declining, suggests that birds can shift between breeding areas, 
260 performing movements towards better conserved habitat. Causal factors influencing site-level

261 variability in population trends will be subjected to a further in-depth analysis including changes

262 in habitat availability, land use cover and the prevalence of anthropogenic infrastructures.

\section{Conclusion}

We conclude that despite the importance of SPAs still holding important breeding populations and grassland habitat, the network of protected areas was not effective in buffering against the bustard population decline. This case study shows that the mere designation of SPAs in European farmland may not be enough to secure species populations and has to be combined with management (mainly agricultural) policies and investment directed at maintaining not only habitat availability but also habitat quality.

\section{Acknowledgements}

We are indebted to all that carried out the field work: Nuno Sequeira, José Paulo Martins, Fernando Abegão, Joaquim Pífano, Joana Alves, Domingos Leitão, Carlos Cruz, Ivan Kljun, Rui Morgado, Pedro Salgueiro, Luís Venâncio, Henrique Velez, Rui Pedroso, Nuno Faria, Rita Alcazar, Carlos Pacheco, Bruno Martins, Ricardo Silva, Paulo Marques, Hugo Lousa, Pedro Rocha, Fernando Queirós, João Carlos Claro, Carlos Carrapato, Cristina Cardoso, Teresa Silva, 
280 Fernanda Romba, Eunice Pereira, Ana Martins, Célia Medeiros, Carlos Franco, Conceição conde, 281 Pedro Alverca, Agostinho Tomás, Raquel Ventura, David Carvalho, Pedro Capa. We would also 282 like to acknowledge the review of Adrián Regos that considerably improved the manuscript.

\section{References}

286

287

288

289

290

291

292

293

294

295

296

297

298

299

300

BirdLife International. 2004. Birds in the European Union: a status assessment. BirdLife International, Wageningen, the Netherlands.

Cabeza M. 2013. Knowledge gaps in protected area effectiveness. Animal Conservation 16: 381-382 DOI: 10.1111/acv.12070.

De Juana E, Martínez C. 1996. Distribution, abundance and conservation status of the Little Bustard Tetrax tetrax in the Iberian Peninsula. Ardeola 43: 157-167.

De Juana E. 2009. The Dramatic Decline of the Little Bustard Tetrax tetrax in Extremadura (Spain). Ardeola 56: 119-125.

Equipa Atlas. 2008. Atlas das Aves Nidificantes em Portugal (1999-2005). Instituto da Conservação da Natureza e da Biodiversidade, Sociedade Portuguesa para o Estudo das Aves, Parque Nacional da Madeira e Secretaria Regional do Ambiente e do Mar. Assirio and Alvim, Lisbon.

García de la Morena ELG, Morales MB, Bota G, Silva JP, Ponjoan A, Suárez F, Mañosa S, De Juana E. 2015. Migration patterns of Iberian little bustards Tetrax tetrax. Ardeola 62: 95-112. DOI: http://dx.doi.org/10.13157/arla.62.1.2015.95. 
301

302

303

304

305

306

307

308

309

310

311

312

313

314

315

316

317

318

319

320

Donald PF, Sanderson FJ, Burfield IJ, Van Bommel FPJ. 2006. Further evidenceof continentwide impacts of agricultural intensification on European farmlandbirds, 1990-2000. Agriculture, Ecosystems and Environment 116: 189-196. DOI: http://doi.org/10.1016/j.agee.2006.02.007.

Gamero A, Brotons L, Brunner A, Foppen R, Fornasari L, Gregory RD, Herrando S, Hořák D, Jiguet F, Kmecl P, Lehikoinen A, Lindström Å, Paquet J-Y, Reif J, Sirkiä PM, Škorpilová J, van Strien A, Szép T, Telenský T, Teufelbauer N, Trautmann S, van Turnhout CAM, Vermouzek Z, Vikstrøm T, Voříšek P. 2017. Tracking Progress Toward EU Biodiversity Strategy Targets: EU Policy Effects in Preserving its Common Farmland Birds. Conservation Letters DOI:10.1111/conl.12292.

Inchausti P, Bretagnolle V. 2005. Predicting short-term extinction risk for the declining Little Bustard (Tetrax tetrax) in intensive agricultural habitats. Biological Conservation 122: 375-384. DOI:10.1016/j.biocon.2004.08.001.

INE. 2012. Recenseamento Agrícola. Available at http://www.ine.pt/xportal/xmain?xpid=INE\&xpgid=ine base_dados $($ accessed 9 October 2017).

Iñigo A, Barov B. 2010. Action plan for the little bustard Tetrax tetrax in the European Union. SEO|BirdLife and BirdLife International for the European Commission.

Jiguet F. 2001. Arthropods in diet of Little Bustards Tetrax tetrax during the breeding season in western France. Bird Study 49,105-109 
321 Jiguet F, Arroyo B, Bretagnolle V. 2000. Lek mating system: a case study in the little bustard

322 Tetrax tetrax. Behavioural Process 51: 63-82. DOI: http://doi.org/10.1016/S0376-

323 6357(00)00119-4.

324

325

326

327

328

329

330

331

332

333

334

335

336

337

338

339

340

341

342

Leverington F, Costa KL, Pavese H, Lisle A, Hockings M. 2010. A global analysis of protected area management effectiveness. Environmental Management 46: 685-698. DOI: 10.1007/s00267-010-9564-5.

Marcelino J, Moreira F, Mañosa S, Cuscó F, Morales MB, García de la Morena EL, Bota G, Palmeirim JM, Silva JP. 2017. Long term tracking study of the little bustard in Iberia shows high anthropogenic mortality. Bird Conservation International. DOI: $10.1017 / \mathrm{S} 095927091700051 \mathrm{X}$

Marton-Lefèvre J. 2014. Planet at the crossroads. Science 346: 525. DOI: 10.1126/science. 1261787 .

Mañosa S, Bota G, Estrada J, Cuscó F. 2015. Una oportunidad para el sisón en Cataluña. Quercus 356: 24-35.

Miteva DA, Pattanayak SK, Ferraro PJ. 2012. Evaluation of biodiversity policy instruments: what works and what doesn't? Oxford Review in Economic Policy 2: 69-92. DOI: 10.1093/oxrep/grs00947.

Morales MB, García JT, Arroyo B. 2005. Can landscape composition changes predict spatial and annual variation of little bustard male abundance? Animal Conservation 8: 167-174. DOI: $10.1017 / \mathrm{S} 1367943005001988$.

Morales MB, Traba J, Carriles E, Delgado MP, Paula A, García de la Morena EL. 2008. Sexual differences in microhabitat selection of breeding little bustards Tetrax tetrax: 
Ecological segregation based on vegetation structure. Acta Oecologica 34: 345-353. DOI: http://doi.org/10.1016/j.actao.2008.06.009

Morales MB, Traba J, Arroyo B. 2015. El declive del sisón en el centro de España. Quercus 365: 36-43.

Moreira F, Silva JP, Estanque B, Palmeirim JM, Lecoq M, Pinto M, Leitão D, Alonso I, Pedroso R, Santos E, Catry T, Silva P, Henriques I, Delgado A. 2012. Mosaic-level inference of the impact of land cover changes in agricultural landscapes on biodiversity: a case-study with a threatened grassland bird. PLoS One 7: e38876. DOI:

Nakagawa S, Schielzeth H. 2013. A general and simple method for obtaining $\mathrm{R}^{2}$ from http://dx.doi.org/10.1371/journal.pone.0038876.

355

356

357

358

359

360

361

362

363 Generalized Linear Mixed-effects Models. Methods in Ecology and Evolution 4: 133-142. DOI: 10.1111/j.2041-210x.2012.00261.x.

Orlikowska EH, Roberge JM, Blicharska M, Mikusiński G. 2016. Gaps in ecological research on the world's largest internationally coordinated network of protected areas: A review of Natura 2000”. Biological Conservation 200: 216-227. DOI: http://doi.org/10.1016/j.biocon.2016.06.015.

Pellissier V, Touroult J, Julliard R, Siblet JP, Jiguet F. 2013. Assessing the Natura 2000 network with a common breeding birds survey. Animal Conservation 16: 566-574. DOI: $10.1111 /$ acv.12030.

Pimenta S, Fernandes L, Minhoto, M. 2015. The evolution of the farm structure and characteristics of the producers from the region Alentejo in the last 25 years. In: Rego MC, 
Dentinho T eds. $20^{\text {th }}$ ADPR Congress: Renaissance of the Regions of Southern Europe.

University of Açores, Angra do Heroísmo, Portugal, 1308-1319.

366

367

368

Pinto M, Rocha P, Moreira F. 2005. Long-term trends in great bustard (Otis tarda) populations in Portugal suggest concentration in single high quality area. Biological Conservation 124: 415-423. DOI: http://doi.org/10.1016/j.biocon.2005.01.047.

\section{Ribeiro PF, Santos JP, Bugalho MN, Santana J, Reino L, Beja P, Moreira F. 2014.} Modelling farming system dynamics in High Nature Value Farmland under policy change. Agriculture, Ecosystems and Environment 183: 138-144. DOI: http://doi.org/10.1016/j.agee.2013.11.002.

Sanderson FJ, Pople RG, Ieronymidou C, Burfield IJ, Gregory RD, Willis SG, Howard C, Stephens PA, Beresford AE, Donald PF. 2016. Assessing the performance of EU nature legislation in protecting target bird species in an era of climate change. Conservation Letters 9: 172-180. DOI: 10.1111/conl.12196.

\section{Santana J, Reino L, Stoate C, Borralho R, Carvalho CR, Schindler S, Moreira F, Bugalho} MN, Ribeiro PF, Santos JL, Vaz A, Morgado R, Porto M, Beja P. 2014. Mixed effects of long-term conservation investment in Natura 2000 farmland. Conservation Letters 7: 467-477. DOI: 10.1111/conl.12077.

\section{Silva JP, Leitão D, Santos E, Moreira F, Prego I, Pinto M, Lecoq M, Catry T, Pedroso R.} 2006. Preliminary results of the little bustard's census in Alentejo (Portugal). In: Leitão D, Jolivet C, Rodriguez M, Tavares J, Eds. Bustard conservation in Europe in the last 15 years: current trends, best practice and future priorities. RSPB/BirdLife, Bedfordshire, $55-59$. 
386 Silva JP, Faria N, Catry T. 2007. Summer habitat selection of the threatened little bustard 387 Tetrax tetrax in Iberian agricultural landscapes. Biological Conservation 139: 186-194. DOI: http://doi.org/10.1016/j.biocon.2007.06.013.

389

390

391

392

393

394

395

396

397

398

399

400

401

Silva JP, Palmeirim JM, Moreira F. 2010. Higher breeding densities of the threatened little bustard Tetrax tetrax occur in larger grassland fields: Implications for conservation. Biological Conservation 143: 2553-2558. DOI: http://doi.org/10.1016/j.biocon.2010.06.023.

Silva JP, Palmeirim JM, Alcazar R, Correia R, Delgado A, Moreira F. 2014. A spatially explicit approach to assess the collision risk between birds and overhead power lines: A case study with the little bustard. Biological Conservation 170: 256-263. DOI: http://doi.org/10.1016/j.biocon.2013.12.026.

Schulz H. 1985. A review of the world status and breeding distribution of the little bustard. Bustard Studies 2: 131-152.

Watson JE, Dudley N, Segan DB, Hockings M. 2014. The performance and potential of protected areas. Nature 515: 67-73. DOI: 10.1038/nature13947. 


\section{Table $\mathbf{1}$ (on next page)}

Summary statistics of the models exploring little bustard density and grassland availability between surveys and area protection status

The reference level represents SPAs in the 2003-2006 survey. Conditional and marginal $r^{2}$ values were 0.65 and 0.36 for the little bustard density model and 0.68 and 0.09 for the grassland availability model. 


\begin{tabular}{|l|c|c|c|}
\hline \multicolumn{1}{|c|}{ Variable } & Estimate & Std. Error & p-Value \\
\hline \multicolumn{4}{|c|}{ Little bustard density model } \\
\hline Intercept & 4.571 & 0.414 & $<0.001$ \\
\hline Non SPAs & -1.938 & 0.412 & $<0.001$ \\
\hline 2016 Survey & -3.215 & 0.557 & $<0.001$ \\
\hline Non SPAs : 2016 Survey & 1.191 & 0.581 & 0.045 \\
\hline \multicolumn{4}{|c|}{ Grassland availability model } \\
\hline Intercept & 14.143 & 1.997 & $<0.001$ \\
\hline Non SPAs & -2.601 & 2.604 & 0.321 \\
\hline 2016 Survey & 1.497 & 1.677 & 0.135 \\
\hline Non SPAs : 2016 Survey & -4.895 & 2.187 & 0.030 \\
\hline
\end{tabular}

2 


\section{Figure 1}

Location of the study area within Europe and Portugal

(a) Location of Alentejo, the study area, within Europe. The polygons outlined in black show the network of key conservation areas for farmland birds, classified as SPAs. Dark grey areas indicate the survey areas within SPAs. The white areas represent the survey areas outside SPAs but within potential habitat for the little bustard, which were stratified across the four sub-regions of Alentejo; Alto, Centro, Baixo and Litoral. (b) Example of a network of survey points placed along available dirt tracks within a survey area and used to estimate the density of breeding males.

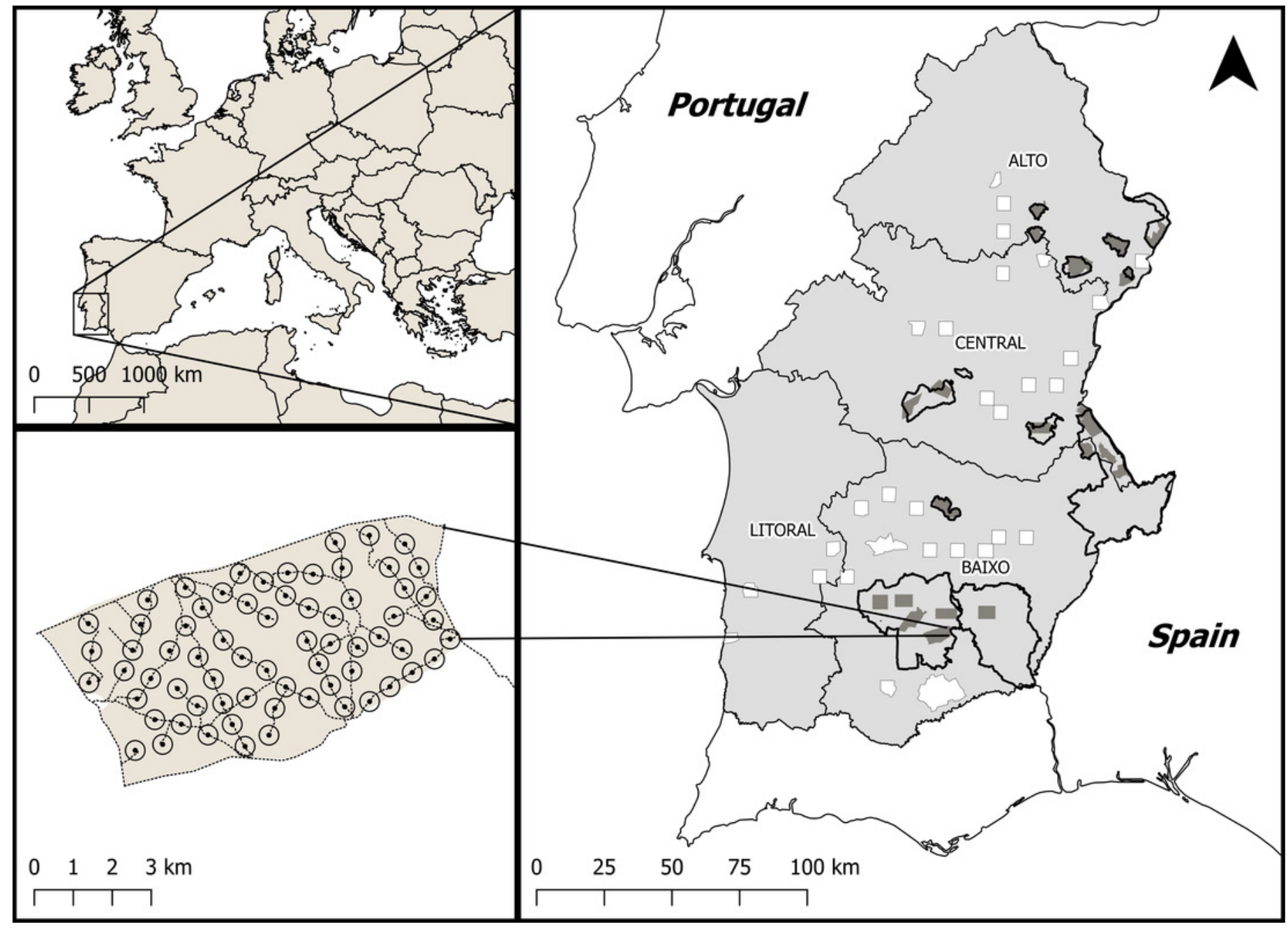


Figure 2

Effects of protection status (SPA versus non-SPA) and survey period (2003-2006 or 2016) on population densities and on the amount of suitable grassland habitat

Comparison of: a) male little bustard densities (males $/ \mathrm{km}^{2}$; mean and \pm standard error) and b) grassland area (males $/ \mathrm{km}^{2}$; mean and \pm standard error), within SPAs and outside SPAs (non-SPAs) in 2003-2006 and 2016.
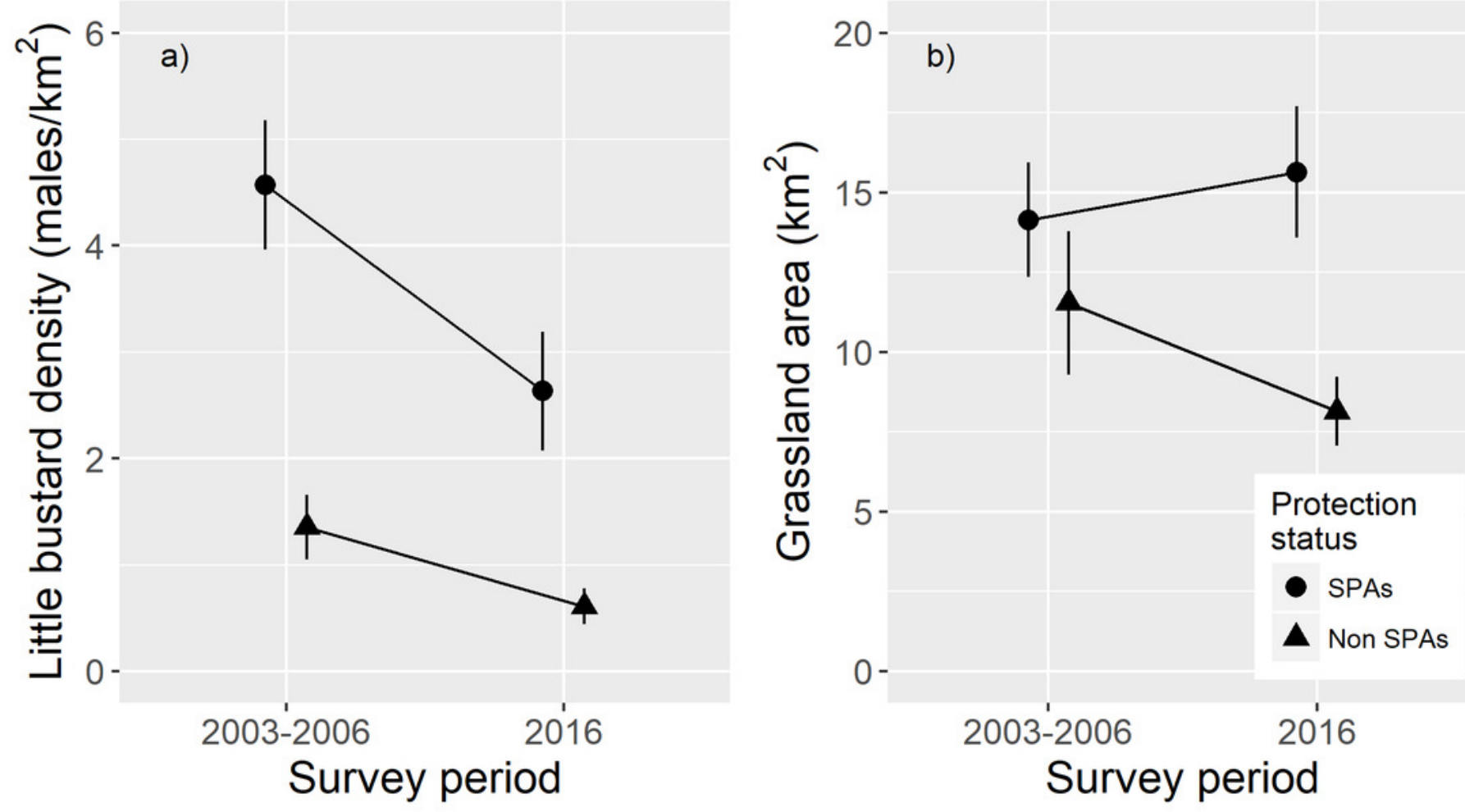